\title{
Historical and SEM-EDS Analysis of a 14th-16th Century Triangular Crucible from Sandomierz, Poland
}

\author{
Piotr Werens $^{a}$ Ireneusz Piwoński $^{b}$ and Aneta Kisielewska ${ }^{c}$
}

\begin{abstract}
The collection of the District Museum in Sandomierz holds a previously unidentified and unpublished triangular ceramic crucible. After at least fifty years since its acquisition, it was possible to obtain detailed information about its chemical composition and presumed use in the past. Based on analogies from Central Europe, it is possible to date it typologically to the 14th-16th centuries. The stamp mark on the bottom of the crucible points to Tulln in Austria as the place of its origin. The SEM-EDS analysis revealed the presence of graphite in the ceramic mass of the vessel as well as carbon and iron compounds on its inner wall, which indicates its possible use in the production of steel by carburising of iron.
\end{abstract}

KEY-WORDS: crucible, post-medieval, graphite, iron, carburising, SEM-EDS analysis

\section{INTRODUCTION}

The aim of the work is to present a previously unpublished triangular ceramic crucible with a stamp (Fig. I), kept in the collection of the Archaeological Department of the District Museum in Sandomierz. The vessel was acquired before the year 1970. It comes from Sandomierz, probably from the Old Town area. There is no detailed data concerning its discovery. In the museum inventory the crucible has the signature MS-I2Io/a. This specimen was initially believed to be a medieval vessel stove tile, and this paper is a consequence of its re-interpretation.

The vessel is $200 \mathrm{~mm}$ high with the side length of $160 \mathrm{~mm}$, and measures $c .165 \mathrm{~mm}$ in diameter and $125 \mathrm{~mm}$ diameter at the base. The bottom is $30 \mathrm{~mm}$ thick and the walls

a Archaeological Department of the District Museum in Sandomierz, e-mail: p.werens@zameksandomierz.pl; https://orcid.org/oooo-0003-1804-5824

$b$ Faculty of Chemistry, University of Lodz, Department of Materials Technology and Chemistry, e-mail: ireneusz.piwonski@chemia.uni.lodz.pl; https:/orcid.org/oooo-0002-6505-3088

$c$ Faculty of Chemistry, University of Lodz, Department of Materials Technology and Chemistry, e-mail: aneta.kisielewska@chemia.uni.lodz.pl; https://orcid.org/oooo-0oo2-8545-643I 


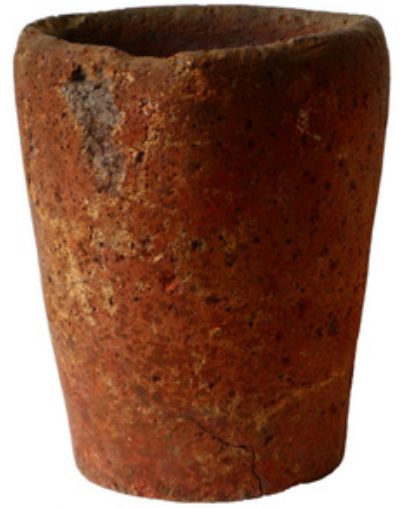

a

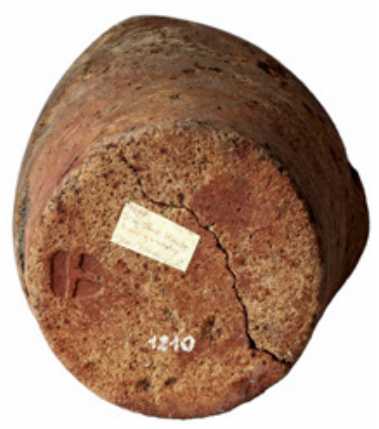

b

Fig. 1. Triangular crucible from Sandomierz, Poland: a - The crucible in the collection of the District Museum in Sandomierz, b - Bottom of the crucible with the visible stamp. Photo by M. Banaczek.

at the spout are $19 \mathrm{~mm}$ thick. The crucible weighs $3.2 \mathrm{~kg}$. Viewed from above, the vessel has an opening in the form of an equilateral triangle with slightly arced sides curving outside (Fig. 2). The rim is rounded, bending slightly towards the inside of the vessel. On the one edge of the spout (just by one of the corners of the triangular vessel) there is a shallow notch $30 \mathrm{~mm}$ long, made before the vessel was fired. The bottom of the vessel is flat, with a stamped mark resembling a coat of arms with St. Anthony's cross or the letter T (Figs Ib and 2). The mark measures $24 \mathrm{~mm}$ (height) by 2I $\mathrm{mm}$ (maximum width). On the inside, the bottom of the crucible is slightly concave-shaped. The rough and coarse outer surface of the crucible is reddish-brown in colour, while the interior is dark-red
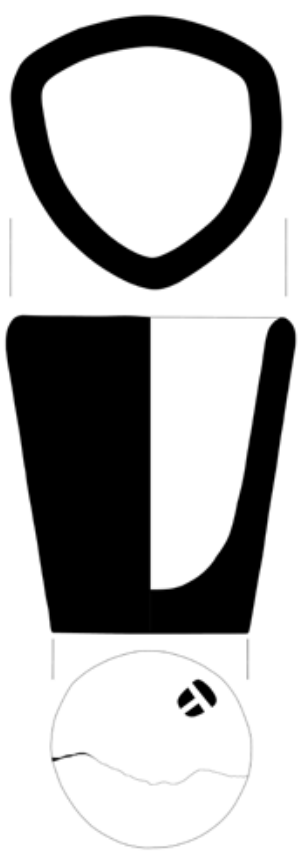

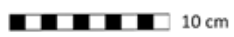

Fig. 2. Ceramic crucible in the collection of the District Museum in Sandomierz (inv. no MS-1210/a), 14th-16th c. Graphic design by P. Werens. 
Historical and SEM-EDS Analysis of a I4th-I6th Century Triangular Crucible from Sandomierz, Poland $\mid$ III

and brown with much dark discolouration and a rusty coating visible in places. On the outer surface of the vessel, one can see cracks and multiple chips in the outer layer of clay. On the inner surface there are visible traces that it was thrown on the wheel. The crucible was made from clay containing iron compounds, thinned with a fine-grained temper of sand, and a coarser-grained admixture (rock pieces up to app. $2 \mathrm{~mm}$ in diameter) admixtures. Both the patchy colouring on the interior and the exterior of the crucible and its porous surface result from use and indicate contact with high temperatures.

\section{ICONOGRAPHY}

Representations of triangular crucibles can be found e.g., on the illustrations in the I6th-century works devoted to mining and metallurgy: De Re Metallica by Georgius Agricola (Agricola 2000: 212, 407) and Beschreibung allerfürnemisten Mineralischen Ertzt, und Bergwercks arten, wie dieselbigen, und eine jede insonderheit, der Natur und Eigenschafft nach, auff alle Metale Probirt by Lazar Ercker (1974: 49; Fig. 3). In 1872

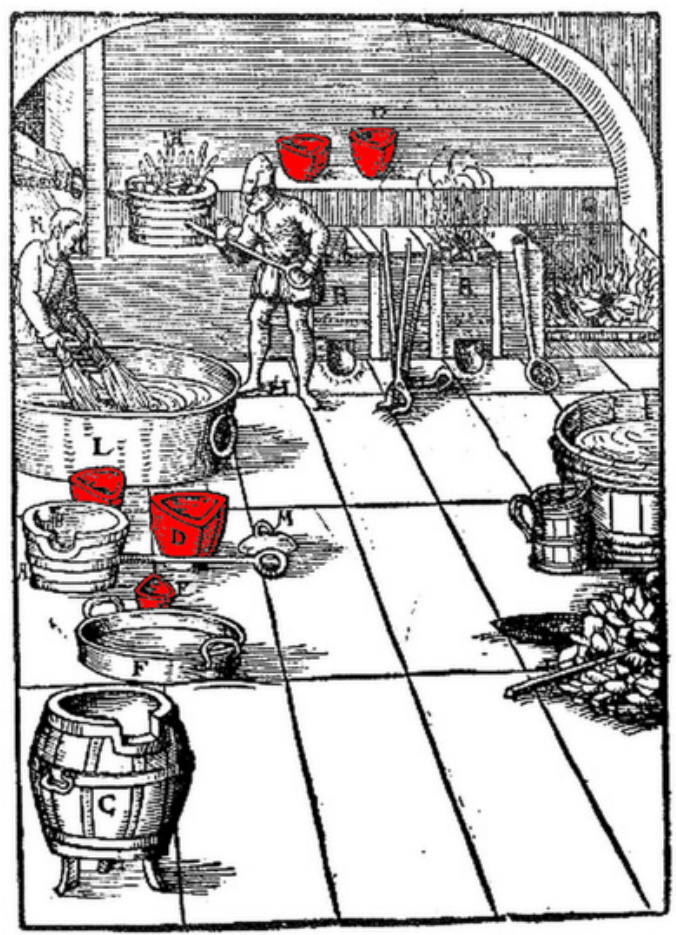

Fig. 3. Presenting the process of assaying the silver content (after: Ercker 1974: 49). 
II2 Piotr Werens, Ireneusz Piwonski and Aneta Kisielewska

the reprint of the original work Narrenschiff by Sebastian Brant from I494, an image of a crucible was included in the chapter entitled: Von Falsch und Betrug (Brant 1872: 266). We can also find them in two illustrations by Christoph Murer (Murer and Rordorf I622: I, XIX) known as Alchimia and Fidei Exploratio.

\section{ANALOGIES}

In Poland triangular crucibles have been known from the research carried out in Krakow-Wawel (four small vessels found in post medieval layers in different parts of the Royal Castle and The Wawel Hill area; Lichończak-Nurek 2007: 4I7-4I8), Nysa - Królowej Jadwigi Street (four vessels found in a medieval well; Romiński 1972), Bytom (two vessels with no detailed information about place of discovery available; Romiński 1972: 73), the city moat in Wroclaw (Wiśniewski 1993: Fig. IIe) or the Market Square in Sieradz (Kufel-Dzierzgowska 2007: 38).

They have also been discovered in different regions of Central Europe. In Czechia they have been found in Prague - Nové Mesto (Cymbalak and Matějková 20I2: 52, fig. 16), Olomouc (Nekuda and Reichertová 1968: 390, fig. LXXXV.I - no detailed information about place of discovery available), as well as on four sites in Brno Chorázova Street (Novotný 1964: 66; tab. 33), Dominikánská Street (Hložek et al., 2004), Mečová Street (Gregerová et al., 20II: 48) and in Náměstí Svobody (from the site of the former church of St. Nicholas; Novotný 1966: Tab. 23.8). In Austria, they have been discovered in Tulln an der Donau (Tulln-Bahnhofstraße; Cech 1989: 216, taf. 36) and the place known as the Alchemist's Workshop in Oberstockstall (Soukup and von Osten 1992: I2, fig. I). At the latter site there were discovered an impressive number of about 280 triangular crucibles, of which, however, only 6 were similar in size to the crucible from Sandomierz (a group of the largest crucibles 170-185 mm high; Martinón-Torres 2005: 106, fig. 33). In Hungary, similar triangular crucibles have been found in Sopron (City Hall; Kugler I9or: 74), in the counterfeiter's workshop in the Szuhogy-Csorbakő castle (Varga and Nagy 20I7: fig. 7), on two sites in modern-day Budapest: Hess András tér (Holl 1975: taf. 51, 52; Holl 199I: taf. 2.2) and in the Royal Castle (on the site of a presumed goldsmith's workshop, Holl 1991: 84, taf. 3.2).

The listed crucibles vary in sizes, with the height between a few centimetres and over $20 \mathrm{~cm}$.

All the above-mentioned finds are dated to the period between the I 4 th and the I6th centuries, to a varying degree of certainty. The form of the vessels is dictated by their utilitarian function (Cech 1989: 178) and for this reason seem unlikely to vary in form chronologically. This means that it is difficult to date specimens devoid of their context on the basis of form. Examples of later triangular crucibles from Poland 
Historical and SEM-EDS Analysis of a I4th-I6th Century Triangular Crucible from Sandomierz, Poland $\mid$ IIJ

(dated to the turn of the I8th and I9th centuries) are known from the Warsaw mint (Borowska 20I2: 135, fig. 6) and from the site at 6 Świętojańska Street in Gdansk, where they were used for bronze casting (Dąbal 20I8: IO2).

\section{T-MARK}

The stamped mark on the bottom of the vessel (Figs Ib and 2) might help to establish the provenance of the vessel. Imre Holl presented a list of over 30 sites where various types of pottery with the above-mentioned mark were discovered. The majority of those sites was located in the vicinity to the Danube river along the section between Passau and Budapest (Holl 1975: taf. 54).

The stamp was present on different types of pottery found e.g., in Hungary (Budapest, Visegrad, Köszeg, Sopron and Szuhogy; Holl 1975: I36-I40), Slovakia (Bratislava; Habovštiak 1959: 466), Czechia (Prague; Cymbalak and Matějková 20I2: 52; Brno; Novotný 1966: tab. 23.8) and Austria (Tulln an der Donau; Cech 1989: taf. I4, 36; Oberstockstall; Soukup and von Osten 1992: I2). Putting the stamp on vessels with diverse forms such as bowls, pots, jugs, crucibles, as well as tiles, indicates that the mark was not related to the function or size of the vessel. It should be interpreted as a signature of the workshop or a quality mark. Vladimir Nekuda and Květa Reichertová quote, after Alfred Walcher von Molthein, a regulation of the Vienna City Council from I43I ordering potters to use a stamp to mark only the vessels with an addition of graphite (Nekuda and Reichertová 1968: 96).

The stamp found on the bottom of the crucible from Sandomierz is identical to the stamps interpreted as the signature of the workshop located in Tulln an der Donau in Lower Austria (Wiesinger 1937: I13; taf. 5.I4-16; Holl 1975: 135, Martinón-Torres and Rehren 2009: 65; in the listed publications no precise data on the place of discovery). The coat of arms of the town of Tulln an der Donau still has a similar form representing the letter T inscribed within a shield (Ströhl 1904: 25; Taf. IV).

\section{ANALOGIES OF CRUCIBLES WITH T-MARK}

Similar finds of triangular crucibles marked on the bottom with a stamp, such as can be seen on the crucible from the collection of the District Museum in Sandomierz, were recorded during excavations at a number of sites in Central Europe. Possibly among the oldest were those found in the research conducted in the vicinity of the former church of St. Nicholas in Brno (Fig. 4b; items dated to the I4th-Isth centuries; Novotný 1966: tab. 23.8). Others were found in Prague - Nové Mesto (Fig. 4a; vessels from the 2 nd half of the Isth - Ist half of the I7th century; Cymbalak and Matějková 


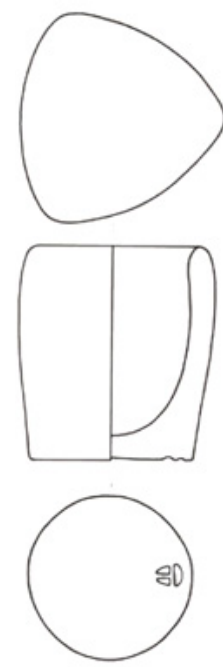

a

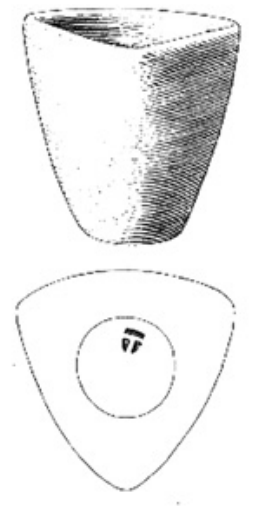

b

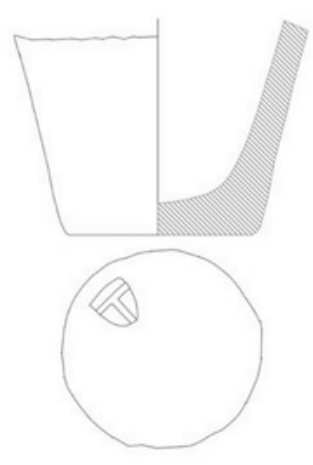

C
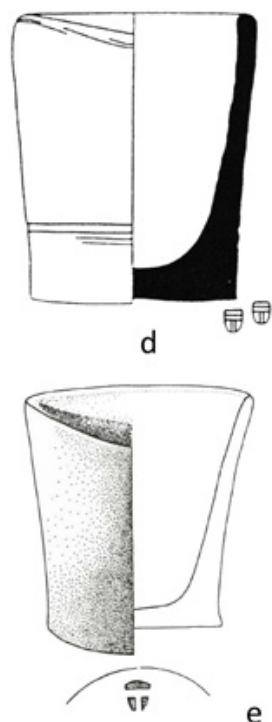

Fig. 4. Finds of crucibles with stamps in the shape of the letter T: a - Prague - Nové Mesto (Cymbalak and Matějková 2012: 52; Fig. 16), b - Brno - St. Nicholas church (Novotný 1966: Tab. 23.8), c - Tulln an der Donau - Bahnhofstraße (Cech 1989: 216, Taf. 36-P2), d - Oberstockstall (Soukup and von

Osten 1992: 12, Fig. 1), e - Budapest - Royal Palace (Holl 1991: 90, Taf. 3-2). Various scales. Graphic design by P. Werens.

20I2: 52, fig. 16). In Oberstockstall examples were found in the so called Alchemist's Laboratory (Fig. 4d; artefacts from the 16th century; Soukup and von Osten 1992: I2, fig. I). Examples also came from: Tulln an der Donau (Fig. 4c; dated to the medieval -post-medieval period; Cech 1989: 216, taf. 36); Hess András tér (found in a cesspit) and the Royal Palace in Budapest (Fig. 4e; on the site of a presumed goldsmith's workshop, finds from the I4th-I5th centuries; Holl I975: taf. 5I, 52; Holl I991: 82, 84). A further example also came from Szuhogy-Csorbakő (I6th century; Holl 1975: 138). The sites from which the finds originated are shown in Fig. 5.

\section{INTERPRETATION}

During the late medieval period and afterwards, triangular crucibles were produced in specialised pottery workshops, e.g., in Grossalmerode in Hesse or Obernzell in Bavaria (Martinón-Torres and Rehren 2009: 5I, 60), as well as in numerous smaller workshops 


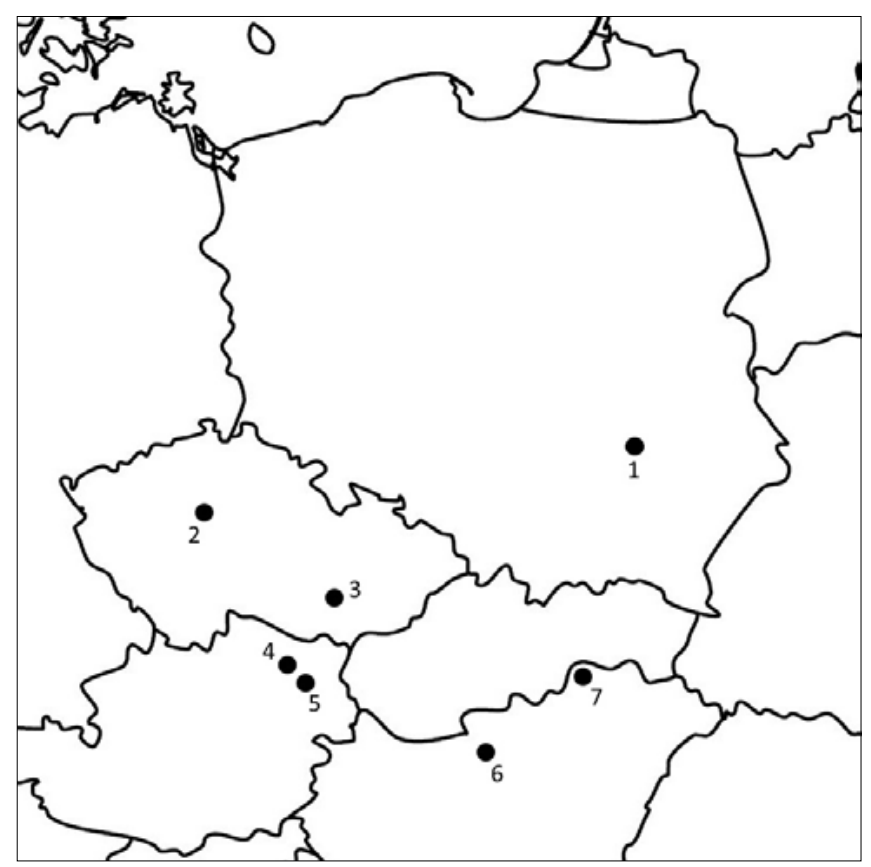

Fig. 5. Map of Central Europe showing finds of triangular crucibles with a T-mark. 1 - Sandomierz, 2 - Prague, 3 - Brno, 4 - Tulln an der Donau, 5 - Oberstockstall, 6 - Budapest, 7 - Szuhogy Csorbakő. Graphic design by P. Werens.

along the Danube associated with the centre in Bavaria (Martinón-Torres and Rehren 2009: 60), and possibly sometimes by metalworkers themselves (Agricola 2000: 213).

Mineral additions e.g., in the form of graphite were frequently used in their production process. The addition of graphite increased the vessels' resistance to high temperatures and chemical substances (Wałowy 1979: 72). However, the question of the source of graphite has not been fully explained. Nekuda and Reichertová (1968: 96) explain its presence as a result of it being imported by Viennese potters from the lands of Bohemia and Moravia. Miroslava Gregerová, Blanka Holubová Závodná, Martin Hložek and Rudolf Procházka (20II: 47) also maintain that material from the deposits located in Moravia was used in the production of graphite pottery vessels. Another possibility is offered by Marcos Martinón-Torres and Thilo Rehren (2009: 67), who suggest the use of clay naturally containing graphite.

A relatively limited number of published triangular crucibles might be the result of difficulties in identifying fragmentarily preserved vessels. But it can also be the consequence of their repurposing - damaged and broken vessels would be crushed and 
II6 | Piotr Werens, Ireneusz Piwoński and Aneta Kisielewska

then added to the clay from which new crucibles were made. Such an indication can be found in the treatise Diversarum artium schedula by Theophilus Presbyter (Teofil Prezbiter 1880: 137). Although it refers to earlier times (IIth/I2th century), a similar piece of information can be found in Agricola's text (Agricola 2000: 213), thus confirming that damaged but high-quality vessels with the addition of the rare mineral were also re-used in the production of new crucibles between the I4th and I6th centuries. In the same place, Agricola describes forming the vessels in brass moulds with the use of special brass pestles. In some crucibles one can see traces of their being wheel-thrown (Lichończak-Nurek 2007: 4I7); according to Martinón-Torres they had been thrown on the wheel and then their spouts were given a triangular shape (Martinón-Torres and Rehren 2009: 50, 54, 60). The temperature of firing was to exceed between $950^{\circ}$ $\mathrm{C}$ and $1050^{\circ} \mathrm{C}$ (Martinón-Torres 2005: III).

Triangular crucibles were almost entirely used for the carrying out various processes related to obtaining and processing metals and were used by:

a) metallurgists, e.g., for smelting ores and melting copper (Agricola 2000: 209, 210), silver (Agricola 2000: 366) and perhaps iron (Wałowy 1979: 73), as well as for producing crucible steel (?; Agricola 2000: 384 ), and carrying out assaying processes (Agricola 2000: 221, 222, 225, 228);

b) goldsmiths (e.g., Holl 1991: 82, 83-84; Hložek et al., 2004: 304);

c) in minting coins (Agricola 2000: 230; Martinón-Torres and Rehren 2009: 60) and by coin counterfeiters (e.g., Varga and Nagy 2017);

d) alchemists (e.g., Brant 1872: 266; Murer and Rordorf I622: I Alchimia, XIX Fidei Exploratio; Soukup and von Osten 1992);

e) and apothecaries (e.g., Lichończak-Nurek 2007: 417, 4I8).

Because there is no information concerning the place and circumstances in which the crucible was discovered, placing the find in a historic context is a difficult task. Archaeological sources do not offer any more precise data concerning metallurgical production in the Sandomierz area during the I4th-16th centuries. Within the settlement on the site Sandomierz - Collegium Gostomianum, dating back to the IIth century, traces of iron processing in the shape of numerous lumps of iron semiproduct and slag have been discovered. Additionally, one of the features discovered on this site was associated with iron production. Slag and iron sponge were also found during the research conducted in the settlement on St James' Hill (Wzgórze Swiętojakubowe, a.k.a. Staromiejskie) dated to the I2th century. Moreover, parts of a smith's tongs were discovered within one of the dwelling features here (Tabaczyński and Buko I982: I5I-I52).

Another vessel in the collection of the museum in Sandomierz, also interpreted as a crucible, comes from the same site. It was probably discovered during the interwar period and there is no detailed data about its acquisition. The vessel is dated to the early-medieval period, has a pot-like shape and rather small dimensions (height: 
Historical and SEM-EDS Analysis of a I4th-I6th Century Triangular Crucible from Sandomierz, Poland $\mid$ II7

$52 \mathrm{~mm}$, diameter: $80 \mathrm{~mm}$ ). The excavations carried out on Wzgórze Staromiejskie in 2015 , revealed an itth century complex of features probably functioned as a metallurgical workshop, where lead and silver were produced and processed (Florek and Stempin 2015: 56).

Historical sources (primarily town records and church registers) are more helpful in researching the period from the I4th to the I6th centuries in this respect. Thus we know that already in the Isth century a guild of metalsmiths existed in Sandomierz (Kiryk I994: I2I). In the 2nd half of the I6th century, several dozen metalworking workshops of craftsmen such as: blacksmiths, swordsmiths, clock-makers and goldsmiths, as well as casting workshops, are believed to have functioned in the town. At that time, metalworking artisans seem to have constituted the majority of the residents in Opatowska Street (Kiryk 1993a: 23). Although Sandomierz was not numbered among major metal production centres, it nevertheless constituted an important centre for manufacturing knives, swords and also possibly armour (Kiryk 1993b: 87-89).

The discovery of the discussed crucible might have been related to that latter branch of metalworking. It should also be emphasised that the 2 nd half of the i6th century was a period of intensive development of forges at multiple sites across Poland, notably about half of their overall number were located in Lesser Poland, concentrated especially in Sandomierz Voivodeship (mainly in the Świętokrzyskie [Holy Cross] Mountains region; Wyrobisz 1978: 15I). The iron obtained in them as a result of the bloomery process was of poor quality; the exception was the so called 'dul', i.e., iron carburised to a lesser degree than steel (Wyrobisz 1978: 147).

The predominant - or even the sole - method of obtaining steel by means of carburising iron employed in Poland until the I6th century was the method which involved roasting iron objects in charcoal dust without an air supply (detailed information on this process in the publications quoted, see e.g., Zientara 1952: 239; Piaskowski 1960: I30-132). The process, currently known as solid (or pack) carburising, is conducted at the temperature of $900-950^{\circ} \mathrm{C}$ and it allows for obtaining a carburised surface layer with I\% concentration and 0.5-2.5 mm thick (Przybyłowicz 1999: 276-279). In the I6th-century work by Giambattistaa della Porta, entitled Magiae naturalis we can find the instruction for hardening the habergeon using the above-mentioned process, carried out in a tightly sealed ceramic vessel with an addition of a powder made by mixing dried oxen hooves, salt, crushed glass and soot (Porta della I658: 307-308). The oxygen supply could have been limited by shutting the crucible with a lid, such as an upturned scorifier (Martinón-Torres 2005: II8). In light of the SEM analysis results, it seems that one of the most likely hypotheses concerning the use of the described crucible is using it as a container in which the above described case hardening process was carried out. 
II8 $\mid$ Piotr Werens, Ireneusz Piwoński and Aneta Kisielewska

\section{SEM-EDS ANALYSIS}

The aim of the SEM-EDS analysis was to determine the content of the ceramic mass of the vessel, and acquire information concerning possible substances traces of which might have remained on the inner sides of the crucible when it was used. Four samples were collected from the crucible in order to analyse the elemental composition and on this basis assessing the chemical content. Analyses were carried out using the scanning electron microscope (SEM) in the laboratory of the Department of Materials Technology and Chemistry at the Faculty of Chemistry at University of Lodz.

The samples were taken with a steel chisel, which was used to remove surface fragments measuring app. $5 \mathrm{~mm} \times 5 \mathrm{~mm}$ from the vessel. Operating conditions for SEM-EDS data collection were as follows: working distance of $5 \mathrm{~mm}$; an accelerating voltage of $\mathrm{I} 5 \mathrm{kV}$; spot size of 3.8 to 5.8 ; live time of Ioo seconds. In order to permit consistent comparisons, images of all the specimens were routinely taken at $650 \times$ magnification.

The fragments of the triangular ceramic crucible were analysed using scanning electron microscopy (SEM; FEI, NovaNanoSEM 450), with a microscope operating at the accelerating voltage of $15 \mathrm{kV}$ and using the ETD detector. The elemental analysis was carried out using energy-dispersive X-ray spectroscopy (EDS). On the basis of the collected spectra and quantitative analysis, the chemical content of the examined ceramic material was estimated.

Four fragments of the vessel were collected for the analysis: Sample I was collected from the outer wall surface, i.e., the original surface of the vessel; Sample 2 was collected from the outer wall surface, i.e., the previously damaged spot; Sample 3 was collected from the inner wall surface, i.e., from the original interior surface of the vessel covered with a yellowish coating; Sample 4 was collected from the interior surface of the vessel bottom, i.e., the original inner surface of the vessel bottom covered with a rusty-coloured coating. The results of the analysis are presented in Table I.

The analysis of the undamaged exterior wall (sample I) carried out in two spots (spot I and 2) indicated that in both places the pottery mass has a similar content and consists mostly of silicon and aluminium, so its content is typical for a pottery mass based on ferric clay. Moreover, carbon was discovered in both spots (spot I). However, the chemical content of the material collected in the previously damaged spot (so analysed material from deeper layers of the vessel - sample 2) shows more diversity. In the first analysed spot (sample 2 - spot I), just like in the first sample, silicon, aluminium and iron are predominant with an admixture of sodium, potassium and magnesium. However, in the second spot (sample $2-$ spot 2) the carbon content was only discovered in the form of a large patch having the size of several hundred micrometres. The obtained chemical content and the topography of SEM images suggests that it most likely is carbon in the form of graphite (or another form of carbon) visible in a SEM photograph as a dark area. This is also confirmed by the 
Historical and SEM-EDS Analysis of a I4th-I6th Century Triangular Crucible from Sandomierz, Poland

Table 1. The approximate chemical composition of the ceramic crucible made using the SEM-EDS.

\begin{tabular}{|l|c|c|c|c|c|c|c|c|c|c|}
\hline Sample & \multicolumn{10}{|c|}{ Content [\% wt] } \\
\hline & $\mathrm{Si}$ & $\mathrm{Al}$ & $\mathrm{K}$ & $\mathrm{Na}$ & $\mathrm{Fe}$ & $\mathrm{Ca}$ & $\mathrm{Mg}$ & $\mathrm{P}$ & $\mathrm{C}$ & $\mathrm{O}$ \\
\hline 1 spot 1 & 11 & 6 & 1 & - & 3 & 3 & - & - & 25 & 51 \\
\hline 1 spot 2 & 10 & 5 & 2 & - & 3 & - & - & - & 44 & 36 \\
\hline 2 spot 1 & 27 & 12 & 2 & 1 & 4 & - & 1 & - & - & 53 \\
\hline 2 spot 2 & - & - & - & - & - & - & - & - & 100 & - \\
\hline 3a spot1 & 39 & 2 & - & - & - & - & - & - & - & 59 \\
\hline 3a spot2 & 2 & 1 & - & - & 2 & 4 & - & - & 63 & 28 \\
\hline 3a spot3 & 17 & 8 & 2 & - & 1 & - & 2 & - & 11 & 59 \\
\hline 3b spot1 & - & - & - & - & - & - & - & - & 100 & \\
\hline 3b spot2 & - & - & - & - & 69 & - & - & - & - & 31 \\
\hline 4a spot1 & 2 & 1 & 1 & - & 11 & 2 & - & 1 & 68 & 14 \\
\hline 4a spot2 & - & - & - & - & - & - & - & - & 100 & - \\
\hline 4a spot3 & 2 & 2 & - & - & 53 & 4 & - & 2 & - & 37 \\
\hline 4b spot1 & - & - & - & - & - & - & - & - & 100 & - \\
\hline 4b spot2 & 1 & - & - & - & 88 & 1 & - & - & - & 10 \\
\hline
\end{tabular}

layered structure of carbon patches with flakes peeling off visible in SEM images (Fig. 6). The lighter area is rich in iron.

Because of the considerable difference in the structure of the inner walls they were analysed twice, i.e., two separate areas on the surface of each sample were analysed, and each of them was also analysed in 2-3 spots. The diverse composition is already clearly visible in the first analysed area ( 3 a -Table I) where, depending on the analysed spot, one can see the presence of silicon with an addition of aluminium (3a spot I), or one can observe the presence of silicon, aluminium, iron and calcium in comparable amounts, as well as a very high carbon content (3a spot 2). On the other hand, in the third analysed spot of that area, silicon and aluminium are predominant again, but additionally there are also potassium, magnesium as well as carbon (3a spot 3). The considerable diversity in the chemical composition was also confirmed by the analysis of the second area ( $3 \mathrm{~b})$, which revealed that it consists of two patches containing only carbon ( $3 b$ spot $\mathrm{I}$ ) or a large amount of iron ( $3 b$ spot 2 ).

The analysis of another sample (sample 4) collected from the inner section, which was also analysed in two areas, seems very interesting. It was found out that particularly 
I20 Piotr Werens, Ireneusz Piwoński and Aneta Kisielewska

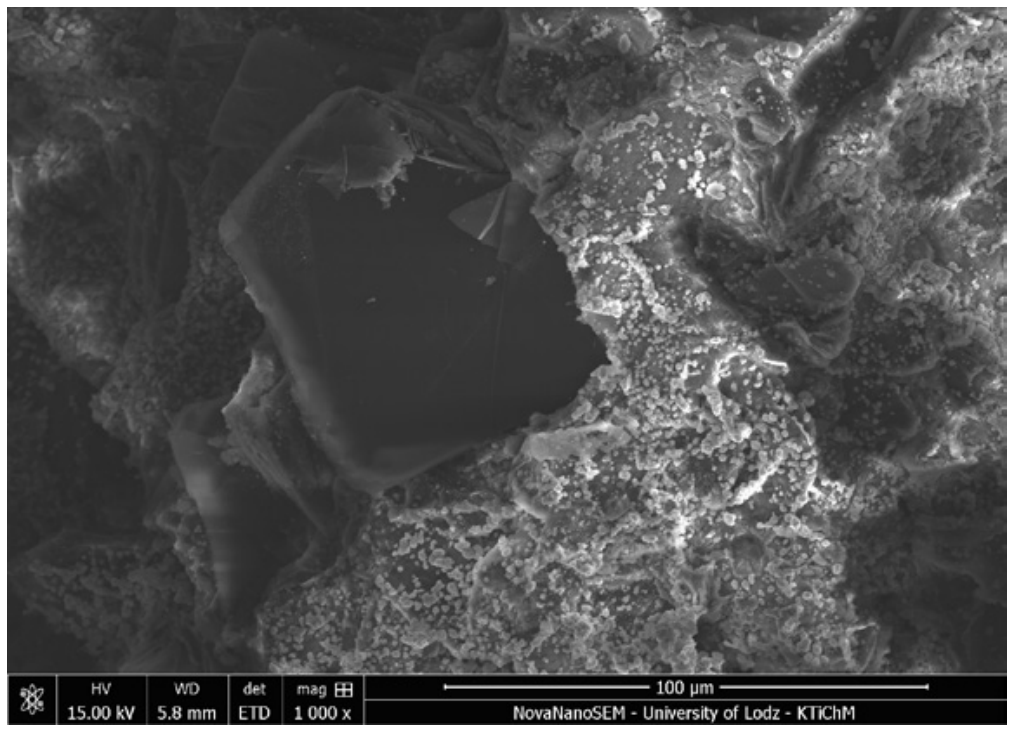

Fig. 6. SEM image of the surface of the sample collected from the inner surface of the ceramic crucible (sample $2-$ spot 2). Photo by I. Piwoński.

iron is present here (4a spots I and 3), while other elements (silicon, aluminium and calcium) occur only in small amounts. There is also a high content of carbon (sample 4 spot I) and patches containing only carbon (4a spot 2). Phosphorus was also found within the analysed area. If we connect both facts, i.e., the occurrence of iron and phosphorus, we can speculate that the vessel was used for smelting or processing of iron from ores containing iron phosphates such as e.g., vivianite. In Poland, vivianite can be found in bog iron ores (Wiwianit 1969: 369) which, in the I6th century, must have been the basic raw material used in the iron production process carried out in the above mentioned numerous forges located in Sandomierz Voivodeship (Ratajczak and Rzepa 20I: 26). However, the concept of using the crucible for iron smelting seems to be contradicted by the lack of traces of slag on the walls of the vessel.

Naturally, another provenance of the phosphorus compounds cannot be ruled out. Characteristic patches consisting solely of carbon ( 4 b spot I) or mainly iron ( 4 b spot 2 ) were also observed in the second analysed area (sample $4 \mathrm{~b}$ ). The data seem to confirm the possibility of using the crucible in the process of pack carburising/case hardening of iron. In that case another explanation for the presence of phosphorus compounds in the analysed sample could be considered, namely that phosphorus compounds were deliberately added during the carburisation process in order to deepen it (Widanka 20I0: 85 ). Alternatively, the presence of metallic iron may have resulted from the process 
Historical and SEM-EDS Analysis of a I4th-I6th Century Triangular Crucible from Sandomierz, Poland $\mid$ I2I

of iron reduction in situ by the action of carbon (from the decomposing graphite) from iron oxides naturally present in the ceramic fabric. A similar phenomenon in other graphite crucibles that were used for silver processing, (i.e., nothing to do with iron metallurgy) was noted e.g., in crucibles from the Convent of San Domenico in L'Aquila (Martinón-Torres and Verrocchio 2008: 107).

The research revealed the presence of iron both in the exterior and the interior wall of the vessel, though their amounts differ considerably from each other. On the one hand, it indicates the use of clay with ferric admixtures; while on the other, it proves that after firing, the vessel was in contact with iron compounds during unidentified technological processes. The rusty residue on the inner wall of the crucible may have resulted from adding iron filings to the ore of the analysed metal (Agricola 2000: 225) or smelting pyrite (Agricola 2000: 367 ). Ercker describes a method of assessing the silver content in iron ore (Ercker 1974: 58) by melting its filings with sulphur. A similar "faint rusty residue" can be found on the inner walls of the crucibles from Nysa (Romiński 1972: 80); the presence of a "thin layer or corrosion" on the crucible from Prague was also confirmed by Tomasz Cymbalak and Kristýna Matějková (20I2: 55).

The analysis revealed that the ceramic surface of the examined vessel contains mainly silicon and aluminium commonly found in clay. The presence of other elements sporadically appearing in various spots of the analysed vessel suggests that the vessel was made from clay of varying chemical composition, perhaps obtained from various sources. Carbon was certainly added to the ceramic material, because its presence in the form of large patches was confirmed in both the outer and the inner wall. The research results suggest that it might be carbon in the form of graphite or charcoal or another form (amorphous carbon, soot etc.). It was also observed that the iron content was much higher in the samples collected from the inside section of the ceramic crucible, which might imply that it was used in processes involving that metal. A considerable amount of phosphorus might indicate the processing of iron with a high content of that element, or of phosphates which might have been admixtures required in the processes carried out with the use of the crucible.

\section{CONCLUSIONS}

The ceramic crucible in the collection of the District Museum in Sandomierz is one of few vessels of this type found in Poland. Based on analogies, its origin can be dated to the period from the I4th to I6th centuries. The mark found on its bottom indicates Austria as a probable place of its origin. Identification of the artefact was possible primarily owing to its well-preserved condition. However, the lack of archaeological context makes it impossible to link it more closely to a probable workshop or an individual working in Sandomierz during the late medieval to post-medieval period. 
I22 $\mid$ Piotr Werens, Ireneusz Piwoński and Aneta Kisielewska

The SEM-EDS analysis allowed the determination of the approximate chemical composition of the surface of the ceramic crucible. A high carbon and iron content was also determined. The analysis results indicate that graphite was added to the clay mixture, while the vessel itself might have been used in steel production or for conducting other processes requiring the use of iron compounds. Further research is needed to confirm the full chemical composition of the triangular crucible analysed in the current paper.

\section{ACKNOWLEDGEMENTS}

For the offered information and assistance in obtaining references we would like to thank: dr Attila Mrenka (Museum in Sopron), Tomasz Cymbalak (Národní památkový ústav w Pradze / The National heritage institute, Prague), dr Joanna Derdowska (University of Silesia in Katowice), Elwira Holc (Museum of Opole Silesia), Sławomir Konik (Konik Archäologie), Jolanta Lasek (the Wawel Royal Castle), Radosław Liwoch (Archaeological Museum in Cracow), Christina Neureiter (Novetus GmbH, Vienna), and Jacek Chlastawa (Museum of Pottery in Bolesławiec). We would also like to thank dr Andrzej Przychodni (Historical and Archaeological Museum in Ostrowiec Świętokrzyski) and Adrian Wrona (Świętokrzyskie Stowarzyszenie Dziedzictwa Przemysłowego) for their valuable insight.

\section{Translated by Violetta Marzec}

\section{REFERENCES:}

Agricola, J. 2000. O górnictwie i hutnictwie. Dwanaście ksiag. Jelenia Góra.

Borowska, J. 20I2. Tygle mennicze z 2. połowy XVIII wieku - lat 6o. XIX wieku, pochodzące z wykopalisk przy ul. Bielańskiej Io w Warszawie. Warszawskie Materiaty Archeologiczne IO: 13I-I39.

Brant, S. 1872. Sebastian Brands Narrenschiff: Ein Hausschatz zur Ergetzung und Erbauung, erneuert von Karl Simrock. Berlin.

Cech, B. 1989. Mittelalterliche und frühneuzeitliche Keramik aus Tulln, Niederösterreich. Archaeologia Austriaca 73: 167-221.

Cymbalak, T. and Matějková, K. 20I2. Zpracování nálezů ze dvou odpadních jímek a úskalí jejich interpretace. Staletá Praha 28(2): 4I-76.

Dąbal, J. 20I8. Prace odlewnicze w miejskim domu. In: J. Dąbal (ed.), Domy i ich mieszkańcy: w świetle badań archeologiczno-architektonicznych przy ulicy Świętojańskiej 6-7 w Gdańsku: IOI-IIO. Gdańsk.

Ercker, L. 1974. Kniha o prubirstvi. Praha.

Florek, M. and Stempin, A. 20I5. Badania archeologiczne na Wzgórzu Staromiejskim w Sandomierzu w roku 2015. Zeszyty Sandomierskie 40: 55-59. 
Historical and SEM-EDS Analysis of a I4th-I6th Century Triangular Crucible from Sandomierz, Poland

Gregerová, M., Holubová, Závodná B., Hložek, M. and Procházka, R. 2oII. Naturwissenschaftliche Erforschung der mittelalterlichen Keramik aus Brno und Loštice. Beiträge zur Mittelalterarchäologie in Österreich 27: 42-52.

Habovštiak, A. 1959. K otázke tak zvanej kolkovanej keramiky na Slovensku. Slovenská archeológia 8(2): $460-476$.

Hložek, M., Merta, D. and Peška, M. 2004. Ke kovolitectví ve středověkém Brně, nálezy tyglíků z Dominikánské 5. Ve službách archeologie 5: 30I-305.

Holl, I. 1975. Angaben zur mittelalterlichen Schwarzhafnerkeramik mit Werkstattmarken. Mitteilungen des Archäologischen Instituts der Ungarischen Akademie der Wissenschaften 5: 129-150.

Holl, I. I99I. Mittelalterliche Goldschmiede in Buda, Handwerk und Topographie. Beiträge zur Mittelalterarchäologie in Österreich 7: 79-9I.

Kiryk, F. I993a. Terytorium, zabudowa, zaludnienie. In: H. Samsonowicz (ed.), Dzieje Sandomierza, XVI-XVIII w., Tom II, cz. I, I7-40. Warszawa.

Kiryk, F. I993b. Rzemiosło. In: H. Samsonowicz (ed.), Dzieje Sandomierza, XVI-XVIII w., Tom II, cz. I, 84-I2I. Warszawa.

Kiryk, F. 1994. Urbanizacja Matopolski. Województwo sandomierskie. XIII-XVI wiek. Kielce.

Kufel-Dzierzgowska, A. 2007. Najstarsze materiały średniowieczne z badań wykopaliskowych na Rynku w Sieradzu w 1962 r. In: M. Głosek and J. Maik. (eds), Od pradziejów po wspótczesność: archeologiczne wędrówki, Issue 53 of Acta archaeologica Lodziensia: 36-42. Łódź.

Kugler, A. I90I. Rejtélyes bélyegü cseréptárgyakról a soproni múzeumban. Archaeologiai Értesito” 2I: 74-78.

Lichończak-Nurek, G. (ed.). 2007. Kraków: europejskie miasto prawa magdeburskiego I257-I79I: katalog wystawy. Kraków.

Martinón-Torres, M. 2005. Chymistry and crucibles in the Renaissance Laboratory: an archaeometric and historical study. Unpublished $\mathrm{PhD}$ thesis, University of London.

Martinón-Torres, M. and Rehren, Th. 2009. Post-medieval crucible production and distribution: A study of materials and materialities. Archaeometry 5I(I): 49-74.

Martinón-Torres, M. and Verrocchio, V. 2008. Triangular crucibles from the Convent of San Domenico in L'Aquila. Archeologia Postmedievale I2: 97-II3.

Murer, Ch. and Rordorf, J. H. I622. XL emblemata miscella nova: das ist XL underschiedliche ausserlesene newradierte Kunststuck / durch weiland den kunstreichen und weiberümpten Herrn Christoff Murern von Zürych inventiret unnd mit eygener Handt zum Truck in Kupffer gerissen; an jetzo erstlich zuo nutzlichem Gebrauch und Nachricht ... erklaeret durch Johann Heinrich Rordorffen, auch Burgern daselbst. Zürych.

Nekuda, V. and Reichertová, K. 1968. Středověká keramika v Čechách a na Moravè. Brno.

Novotný, B. 1964. Nález pozdněstředověké keramiky v Brně, Chorázově ulici. Přehled Výzkumů 1963: 67-68.

Novotný, B. 1966. Záchranný výzkum základů a okolí zaniklého kostela sv. Mikuláše v Brně. Přehled Výzkumů 1965: 77-79.

Piaskowski, J. 1960. Nawęglanie żelaza w dawnych wiekach. Przegląd Mechaniczny 19(5): I30-134.

Porta della, G. 1658. Natural magick. London.

Przybyłowicz, K. 1999. Metaloznawstwo. Warszawa.

Ratajczak, T. and Rzepa, G. 2oIr. Polskie rudy darniowe. Kraków.

Romiński, W. 1972. Późnośredniowieczne tygle gliniane z Nysy. Opolski Rocznik Muzealny 5(I): 69-86.

Ströhl, H. G. 1904. Städte-Wappen von Österreich-Ungarn. Wien. 
I24 Piotr Werens, Ireneusz Piwoński and Aneta Kisielewska

Soukup, R. W. and von Osten, S. 1992. Das Alchemistenlaboratorium von Oberstockstall. Ein Vorbericht: Der derzeitige Stand des Forschungsprojektes. Mitteilungen, Gesellschaft Deutscher Chemiker I Fachgruppe Geschichte der Chemie 7: II-I9.

Tabaczyński, S. and Buko, A. 1982. Sandomierz. Starożytność - wczesne średniowiecze. Rzeszów.

Teofil Prezbiter, I880. Teofila kaptana i zakonnika O sztukach rozmaitych ksiag troje. Kraków.

Varga, M. and Nagy, Z. D. 2017. Coin Counterfeiting Workshops in Hungary in the Middle and Early Modern Ages. In: B. Zając, P. Koczwara, S. Jellonek and A. Jurkiewicz (eds), Pecunia Omnes Vincit. The coins as an evidence of propaganda, reorganization and forgery, I23-I43. Kraków.

Wałowy, A. 1979. Późnośredniowieczne garncarstwo krakowskie w świetle źródeł archeologicznych. Materiaty Archeologiczne 19: 5-I5I.

Wiesinger, F. 1937. Die Schwarzhafner und die Weißhafner in Oberösterreich. Jahrbuch des Oberösterreichischen Musealvereines 87: 85-175.

Widanka, K. 20Io. Effect of phosphorus on vacuum carburising depth of iron compacts. Archives of Civil and Mechanical Engineering IO(I): 85-91.

Wiśniewski, Z. 1993. Inwentarz zabytków ruchomych pozyskanych podczas eksploracji zasypiska wewnętrznej fosy miejskiej w obrębie wschodniej części Placu Dominikańskiego. Silesia Antiqua 35: $33 \mathrm{I}-354$.

Wiwianit. 1969. Wiwianit. In: Wielka Encyklopedia Powszechna PWN. T. ı2: 369. Warszawa.

Wyrobisz, A. 1978. Przetwórstwo surowców mineralnych i organicznych. In: A. Keckowa and D. Molenda (eds), Historia kultury materialnej w zarysie t. III. Od XVI do potowy XVII wieku, I45-205. WrocławWarszawa-Kraków-Gdańsk.

Zientara, B. 1952. Ze studiów nad historią techniki polskiego hutnictwa żelaznego do XVII wieku. Przeglad Historyczny 43(2): 195-242. 